\title{
The augmentation of distillate yield by using concentrator coupled solar still with phase change material
}

\begin{abstract}
In order to augment the efficiency and distillate yield in the concentrator-coupled hemispherical basin solar still, a phase change material (PCM) was added. Two modes of operation have been studied experimentally, (1) single-slope solar still without the PCM effect, and (2) single-slope solar still with the PCM effect. The temperature of water (Tw), temperature of PCM (TPCM), air temperature (Tair), inner cover temperature (Tic) and outer cover temperature (Toc) were measured. Experimental results indicate that the effect of thermal storage in the concentrator-coupled hemispherical basin solar still increases the productivity by $26 \%$. It was concluded that the productivity greatly increased due to the still integrated with PCM.
\end{abstract}

Keyword: Solar still; Concentrator; Phase change material; Desalination 